\title{
Correction: Thioredoxin Glutathione Reductase from Schistosoma mansoni: An Essential Parasite Enzyme and a Key Drug Target
}

Angela N. Kuntz, Elisabeth Davioud-Charvet, Ahmed A. Sayed, Lindsay L. Califf, Jean Dessolin, Elias S. J. Arnér, David L. Williams

Correction for:

Kuntz AN, Davioud-Charvet E, Sayed AA, Califf LL, Dessolin J, et al. (2007) Thioredoxin Glutathione Reductase from Schistosoma mansoni: An Essential Parasite Enzyme and a Key Drug Target. PLoS Med 4(6): e206. doi:10.1371/journal. pmed.0040206

In the supporting information section of this paper, the structures of oltipraz and safranin in Figure S1 were incorrect. The corrected figure may be found at doi:10.1371/journal.pmed.0040264.sg001 (407 KB DOC).

Citation: Kuntz AN, Davioud-Charvet E, Sayed AA, Califf LL, Dessolin J, et al. (2007) Correction: Thioredoxin

Glutathione Reductase from Schistosoma mansoni: An Essential Parasite Enzyme and a Key Drug Target. PLoS Med 4(8): e264. doi:10.1371/journal.pmed.0040264

Received: July 13, 2007; Accepted: July 13, 2007; Published: August 28, 2007.

Copyright: ( 2007 Kuntz et al. This is an open-access article distributed under the terms of the Creative Commons Attribution License, which permits unrestricted use, distribution, and reproduction in any medium, provided the original author and source are credited. 